\title{
Influence of non-stationarity and auto-correlation of climatic records on spatio-temporal trend and seasonality analysis in a region with prevailing arid and semi-arid climate, Iran
}

\author{
Mahsa MIRDASHTVAN*, Mohsen MOHSENI SARAVI \\ Department of Range and Watershed Management, Faculty of Natural Resources, College of Agriculture and Natural Resources, \\ University of Tehran, Karaj 3158777871, Iran
}

\begin{abstract}
Trend and stationarity analysis of climatic variables are essential for understanding climate variability and provide useful information about the vulnerability and future changes, especially in arid and semi-arid regions. In this study, various climatic zones of Iran were investigated to assess the relationship between the trend and the stationarity of the climatic variables. The Mann-Kendall test was considered to identify the trend, while the trend free pre-whitening approach was applied for eliminating serial correlation from the time-series. Meanwhile, time series stationarity was tested by Dickey-Fuller and KwiatkowskiPhillips-Schmidt-Shin tests. The results indicated an increasing trend for mean air temperature series at most of the stations over various climatic zones, however, after eliminating the serial correlation factor, this increasing trend changes to an insignificant decreasing trend at a 95\% confidence level. The seasonal mean air temperature trend suggested a significant increase in the majority of the stations. The mean air temperature increased more in northwest towards central parts of Iran that mostly located in arid and semiarid climatic zones. Precipitation trend reveals an insignificant downward trend in most of the series over various climatic zones; furthermore, most of the stations follow a decreasing trend for seasonal precipitation. Furthermore, spatial patterns of trend and seasonality of precipitation and mean air temperature showed that the northwest parts of Iran and margin areas of the Caspian Sea are more vulnerable to the changing climate with respect to the precipitation shortfalls and warming. Stationarity analysis indicated that the stationarity of climatic series influences on their trend; so that, the series which have significant trends are not static. The findings of this investigation can help planners and policy-makers in various fields related to climatic issues, implementing better management and planning strategies to adapt to climate change and variability over Iran.
\end{abstract}

Keywords: climate change; trend analysis; stationarity tests; serial correlation; seasonality; arid and semi-arid regions

Citation: Mahsa MIRDASHTVAN, Mohsen MOHSENI SARAVI. 2020. Influence of non-stationarity and auto-correlation of climatic records on spatio-temporal trend and seasonality analysis in a region with prevailing arid and semi-arid climate, Iran. Journal of Arid Land, 12(6): 964-983. https://doi.org/10.1007/s40333-020-0100-z

\section{Introduction}

Water resources decision makers require analysis tools to develop the appropriate strategies for efficient water resources management under changing climate (Sahoo and Smith, 2009; Duan et

\footnotetext{
*Corresponding author: Mahsa MIRDASHTVAN (E-mail: mirdashtevan@ut.ac.ir)

Received 2019-08-23; revised 2019-12-17; accepted 2020-09-12

(C) Xinjiang Institute of Ecology and Geography, Chinese Academy of Sciences, Science Press and Springer-Verlag GmbH Germany, part of Springer Nature 2020
} 
al., 2019). Analyzing the trend and stationarity of climatic variables provides information on understanding climate change and future possibilities (Unal et al., 2012; Zhou et al., 2015; Libanda et al., 2019). The methods for detecting the trend of meteorological series are mainly categorized into parametric and non-parametric methods (Zhang et al., 2006). Compared to the parametric trend tests, the non-parametric ones are more appropriate for naturally observed meteorological time series (Hamed, 2009; Shadmani et al., 2012). The Mann-Kendall (M-K) test (Mann, 1945; Kendall, 1975 ) is one of the most popular non-parametric methods utilized for testing the trend of natural series. Many researchers have used the $\mathrm{M}-\mathrm{K}$ test in different research fields including climatological and hydrological studies (Xu et al., 2003; Zhao et al., 2015; Zhou et al., 2015; Duan et al., 2017). Most of these studies have proven the M-K test as an effective and robust technique for identifying the monotonic trend of natural time series. The M-K test is efficient even if there is a seasonal component in the time series (Hirsch et al., 1982), but it is not robust against the serial correlation of the series which would affect the statistics of the test (Shao and Li, 2011); therefore, different alternatives have been suggested to eliminate the effects of time series auto-correlation (Burn and Elnur, 2002; Aziz and Burn, 2006). Among the various approaches of removing time series auto-correlation, the trend free pre-whitening (TFPW) is an effective approach to remove the first order auto-regression (AR(1)) component. Time series de-trending prior to pre-whitening provides a more accurate estimation of AR(1) compared to the other pre-whitening approaches in serially dependent series. Numerous researchers have used auto-correlation approaches for trend detection in natural time series (Yue and Wang, 2002; Yue et al., 2002; Some'e et al., 2012; Feizi et al., 2014; Ahmad et al., 2015; Toller et al., 2019). Non-stationarity is a common term in climatic and hydrological time series that is in close proximity to the trend. Stationarity in climatic variables means that they fluctuate within an unchanging cover of variability, randomly (Wu et al., 2007); therefore; non-stationarity is a sign of a gradual trend or a sudden shift (Wang et al., 2005). There are few cases which have studied the non-stationarity of climatic series and its effects on climatic series trends both in the world and Iran (Wang et al., 2005; Wu et al., 2007; Sun et al., 2018; Um et al., 2018; Parey et al., 2019 ). As stationarity and trend identification in climatic records provide ideas about better water resources management, it must be considered in climatic modelling investigations.

Iran's natural ecosystem and resources are very vulnerable to the climate variability and change since it is located mostly in the arid and semi-arid regions. A number of researchers have studied the trend of climatic time series in Iran, using different trend detection techniques (Raziei et al., 2005a; Tabari et al., 2011; Some'e et al., 2012; Delju et al., 2013; Feizi et al., 2014; Hosseinzadeh, 2014; Fathian et al., 2015). Delju et al. (2013) argued that the mean precipitation amounts decreased by about $9.2 \%$ in Urmia Lake Basin in northwestern Iran from 1964 to 2005 . Using the M-K test and datasets from 1967 to 2006, Some'e et al. (2012) demonstrated a downward trend for annual precipitation series in $79 \%$ of the stations; furthermore, the results showed a significant reduction in precipitation over the northern Iran. Tabari et al. (2011) assessed the trend of annual precipitation over the western, southern and south-western Iran from 1966 to 2005. They identified that there was no significant trend in the series over this period. In recent years, the frequency and persistence of dry periods have significantly increased over various climatic zones in Iran (Abbaspour and Sabetraftar, 2005; Amiri and Eslamian, 2010; Golian et al., 2015). A high population growth rate in some parts of Iran also in association with adopting inappropriate water management strategies, especially in central arid zones, has caused high pressure on water resources, especially groundwater resources in these areas; so, identifying the trends of the observed climatic series can lead to a better understanding of potential tendency in future and consequently, adopting more effective water management strategies under a changing climate.

The purposes of this research are (1) to characterize the precipitation and mean air temperature trends and seasonality over various climatic zones of Iran before and after applying a pre-whitening approach to demonstrate the effect of serial correlation of the climatic series on their trends; and (2) to analyze the influence of climatic series stationarity on their trend and seasonality. Analyzing the stationarity of climatic records is one of the most important stages before modelling any hydrological system since it can happen as a gradual trend and also a sign of climate change 
(Brockwell and Davis, 1991). Conducting this phase before any climatic and hydrological modelling could allow the researchers to achieve more accurate results and consequently adopt more efficient decisions on climate-related issues.

\section{Materials and methods}

\subsection{Study area and datasets}

Iran is a high plateau $\left(24^{\circ}-40^{\circ} \mathrm{N}, 44^{\circ}-64^{\circ} \mathrm{E}\right)$ located in arid and semi-arid regions of the Earth. Climatically, most parts of Iran are classified as arid and semi-arid (Peel et al., 2007). About 30\% of the precipitation occur in the form of snow and the rest is in rainfall and other forms. Precipitation vary both temporally and spatially. Some regions in the south of the Caspian Sea receive more than $2000 \mathrm{~mm}$ of annual precipitation while annual precipitation is less than $50 \mathrm{~mm}$ in the central and eastern Iran. Most of precipitation occur during autumn and winter because of the association of precipitation with western Mediterranean winds (Alijani, 1995). Due to the high climate variability, as well as the effects of changes in climate variables on other systems, it is vital to study and analyze the trend and stationarity of climatic series based on various climatic zones. Figure 1 shows the geographical location of the study region in association with the stations in various climatic zones over Iran based on the De-Marton climate classification index (Table 1).

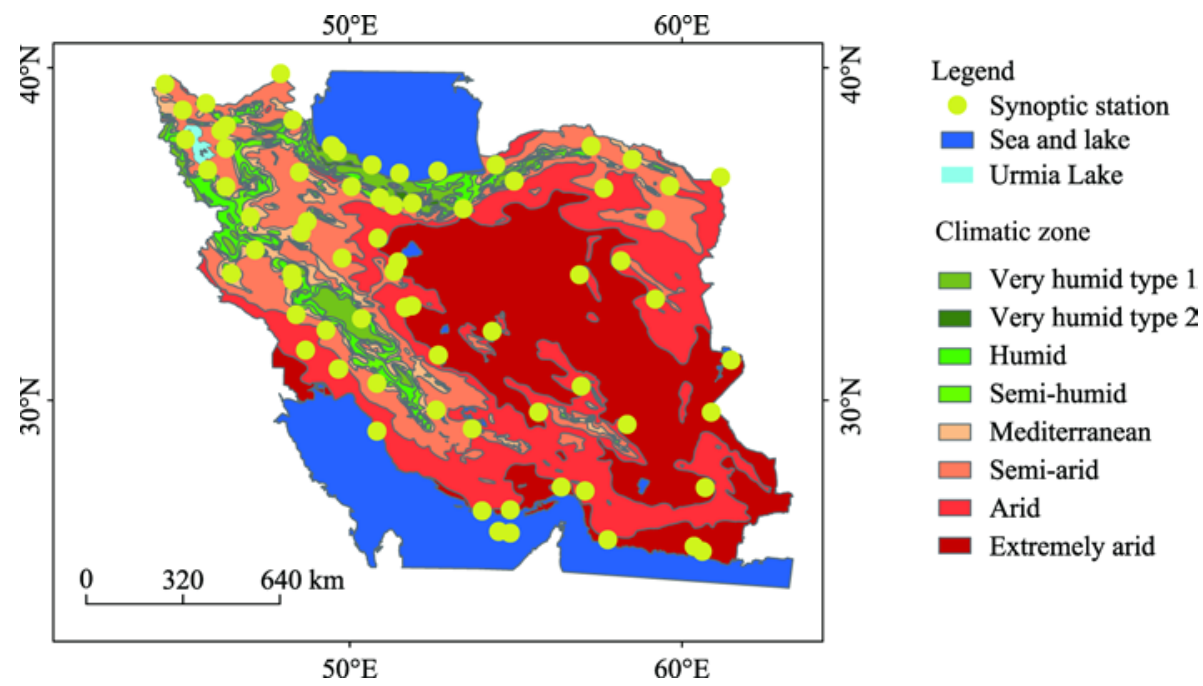

Fig. 1 Location of the synoptic stations in different climatic zones of Iran

Table 1 De-Marton drought coefficient range

\begin{tabular}{ccc}
\hline Climatic zone & Drought coefficient & Number of stations selected \\
\hline Very humid type 1 & $>55.0$ & 4 \\
Very humid type 2 & $35.0-54.9$ & 1 \\
Humid & $28.0-34.9$ & 1 \\
Semi-humid & $24.0-27.9$ & 0 \\
Mediterranean & $20.0-23.9$ & 6 \\
Semi-arid & $10.0-19.9$ & 27 \\
Arid & $5.0-9.9$ & 16 \\
Extremely arid & $<4.9$ & 18 \\
\hline
\end{tabular}

Detecting variability of climatic records requires reliable and integrated time series. In this study, the time series of monthly precipitation and mean monthly air temperature, measured in 73 synoptic stations (1985-2014) over Iran, were selected to determine the trend, seasonality and stationarity of the climatic series. The nearest neighbor approach was used for rebuilding the missing data. The 
randomness and the independence of the series were examined by the runs test and the nonparametric Mann-Whitney test, respectively (Fig. 2). The characteristics of the selected stations were summarized (Table S1).

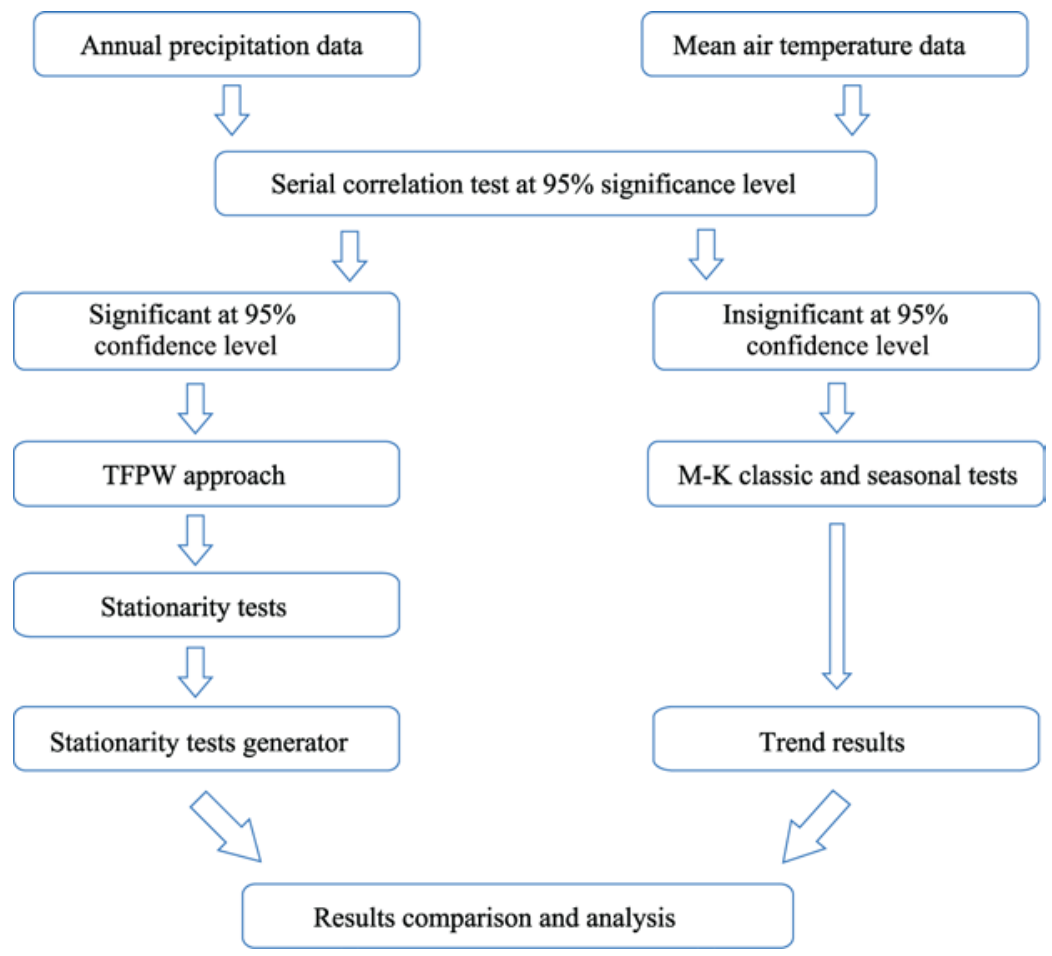

Fig. 2 Procedures and steps of the study

\subsection{Trend and seasonality detection}

The classic M-K test is a non-parametric approach that is utilized in different types of time series to identify the monotonic trend of the records. This test is firstly proposed by Mann (1945) and further developed by Kendall (1975) and finally improved by Hirsch et al. (1991, 1982), who allowed the method to take into account the seasonality. The null hypothesis $\left(\mathrm{H}_{0}\right)$ indicates that the series belongs to an independent population which is identically distributed; otherwise, the alternative hypothesis $\left(\mathrm{H}_{\mathrm{a}}\right)$ shows that the records follow a monotonic trend. The M-K tests are based on the calculation of Kendall's tau measure of association between two samples, which is itself based on the ranks with the samples. The computations assume that the observations are independent (Hosseinzadeh, 2014; Blain, 2015).

In this method, the differences between each observation with all subsequent observations are calculated (Eq. 1).

$$
S=\sum_{k=1}^{n-1} \sum_{j=k+1}^{n} \operatorname{sgn}\left(x_{j}-x_{k}\right),
$$

where $S$ is the number of positive differences minus the number of negative differences; $n$ is the number of data in the time series; and $x_{j}$ and $x_{k}$ are the $j^{\text {th }}$ and $k^{\text {th }}$ data of series, respectively. The sgn function is calculated as Equation 2.

$$
\operatorname{sgn}\left(x_{j}-x_{k}\right)=\left\{\begin{array}{rl}
1 & \text { if }\left(x_{j}-x_{k}\right)>0 \\
0 & \text { if }\left(x_{j}-x_{k}\right)=0 \\
-1 & \text { if }\left(x_{j}-x_{k}\right)<0
\end{array} .\right.
$$

In the next step, the calculation of the variance $S$ is carried out by one of the Equations 3 and 4 , which depends on the number of data in the time series. 


$$
\operatorname{Var}(S)=\left\{\begin{array}{ll}
\frac{n(n-1)(2 n+5)-\sum_{i=1}^{m} t(t-1)(2 t+5)}{18} & \text { if } n>10 \\
\frac{n(n-1)(2 n+5)}{18} & \text { if } n<10
\end{array},\right.
$$

where $n$ and $m$ are the numbers of sequences in which there is at least one duplicate data; $t$ indicates the frequency of the values of the same value in a sequence (number of nodes).

$\mathrm{Z}$ is the statistic obtained from Equation 4,

$$
\mathrm{Z}=\left\{\begin{array}{cc}
\frac{S-1}{\sqrt{\operatorname{Var}(S)}} & \text { if } S>0 \\
0 & \text { if } S=0 \\
\frac{S+1}{\sqrt{\operatorname{Var}(S)}} & \text { if } S<0
\end{array} .\right.
$$

Assuming that the trend test is two-tailed, the null hypothesis is accepted if,

$$
|Z|<Z_{a / 2} \text {, }
$$

where $\alpha$ is the significance level that is considered for testing; and $Z_{\alpha / 2}$ is the standard normal distribution statistic at $\alpha$ significance level.

The seasonal M-K statistics $\left(S_{g}\right)$ is defined as:

$$
S_{g}=\sum_{i=1}^{n-1} \sum_{j=i+1}^{n} \operatorname{sgn}\left(x_{j g}-x_{i g}\right) \quad g=1,2, \ldots, m .
$$

The seasonal M-K statistics for the entire records $(\hat{S})$ is calculated as:

$$
\hat{S}=\sum_{g=1}^{m} S_{g} .
$$

More details about seasonal M-K descriptions and equations can be found in Hirsch et al. (1991).

\subsection{Auto-correlation modification}

The existence of serial correlation could make trend identification too complex which may result in false outcomes for M-K test (Burn et al., 2004). There are several techniques to eliminate serial correlation from a series that the pre-whitening approach is more common among them, although investigators ( Yue et al., 2002; Blain, 2015) indicated that pre-whitening can eliminate some of the trends as removing serial correlation; therefore, another approach calling the TFPW was developed. In this study, the following steps are applied before conducting the M-K test:

Firstly, removing linear trend from the raw time series using Equation 8.

$$
Y_{t}=X_{t}-\beta_{t}
$$

where $X_{t}, \beta_{t}$ and $Y_{t}$ are the series value, linear regression slope of the trend in the raw time series and de-trended series at time $t$, respectively.

Secondly, removing serial correlation if the lag-1 serial correlation coefficient of the de-trended series is statistically significant at $5 \%$ confidence level:

$$
Y_{t}^{\prime}=Y_{t}-r_{1} Y_{t-1} \text {, }
$$

where $Y_{t}^{\prime}$ is the de-trended and pre-whitened series that is referred to as the residual series.

Thirdly, adding the linear trend that was removed at step 1 back to the de-trended or residual series by,

$$
Y_{t}^{\prime \prime}=Y_{t}^{\prime}-\beta_{t}
$$

where $Y_{t}^{\prime \prime}$ is the trend-free pre-whitened series.

\subsection{Stationarity analysis}

If the statistical features of a time series do not vary with time, it is considered as a statistic time series. Stationarity means that the first and second moments of the probability density function of 
a series are independent of time; however, higher moments are not considered stationary. Detecting the stationarity status of time series is essential for finding the origin of the non-stationarity of the series (Brockwell and Davis, 2011). In the current study, Dickey-Fuller (DF) and KwiatkowskiPhillips-Schmidt-Shin (KPSS) stationarity tests are utilized as the common stationarity tests.

\subsubsection{KPSS method}

In the KPSS method, the series is decomposed into the sum of a deterministic trend, a random walk and a stationarity error with the following linear regression model (Kwiatkowski et al., 1992).

$$
X_{t}=r_{t}+\beta_{t}+\varepsilon_{t},
$$

Where $X_{t}$ is a time series; $r_{t}$ is a random walk; $\beta_{t}$ is a deterministic trend; and $\varepsilon_{t}$ is a stationarity error.

In this model, the series is stationary around a deterministic trend and the null hypothesis will be $\sigma_{\mathrm{u}}^{2}=0$. The residuals $e_{t}(t=1,2, \ldots, N)$ are from the regression of $x$ (each record in a time series) on an intercept and time trend, $e_{t}=\varepsilon_{t}$.

The consistent estimation of $\sigma^{2}$ can be constructed from the residuals $e_{t}$ by Equation 12 .

$$
\sigma^{2}(p)=\frac{1}{N} \sum_{t=1}^{N} e_{t}^{2}+\frac{2}{N} \sum_{j=1}^{p} w_{j}(p) \sum_{t=j+1}^{N} e_{t} e_{t-j},
$$

where $p$ is the truncation lag and $w_{j}(p)$ is an optional weighting function.

Then the KPSS statistic is obtained by Equation 13.

$$
\mathrm{KPSS}=N^{-2} \sum_{t=1}^{N} S_{t}^{2} / \sigma^{2}(p) .
$$

\subsubsection{DF method}

The unit root test of DF is one of the most common tests for determining the stationarity of the time series. This test introduces a statistic that has a finite distribution. The performance of this test is carried out using regression models (Wang et al., 2005).

$$
y_{t}=\rho y_{t}-1+X_{t} \delta+u_{t},
$$

where the domain of $t$ is from 1 to $N$ and $u_{t}$ is a random and independent series. If $|\rho|<1$, the time series $y_{t}$ is static and if $\rho=1$ then the series is not static. The value of $\hat{\rho}$ is calculated using the exponential maximal method by Equation 15 .

$$
\begin{gathered}
\hat{\rho}=\frac{\sum_{t=2}^{N} Y_{t} Y_{t-1}}{\sum_{t=2}^{N} Y_{t-1}^{2}}, \\
\hat{t}=\frac{\hat{\rho}-1}{\hat{\sigma}_{p}},
\end{gathered}
$$

where $\hat{\sigma}_{p}$ is the standard least square error for the coefficient $\hat{\rho}$. In this test, the distribution of the test $\hat{t}$ in the $\mathrm{H}_{0}$ and $\mathrm{H}_{\mathrm{a}}$ hypotheses are $\mathrm{H}_{0}(\rho=1)$ or $\mathrm{H}_{\mathrm{a}}(|\rho|<1)$. If the $\mathrm{H}_{\mathrm{a}}$ hypothesis is rejected, the series is unstable; while in the case of the rejection of the $\mathrm{H}_{0}$ hypothesis, the series considers as static.

\section{Results and discussion}

\subsection{Trend detection}

\subsubsection{Mean air temperature}

The results of the serial correlation detection process show the existence of a significant autocorrelation factor among all of the mean air temperature series (Table 2). The TFPW approach should be utilized to modify the results of the M-K test. 
Table 2 Serial correlation coefficient of mean air temperature and precipitation time series

\begin{tabular}{|c|c|c|c|c|c|}
\hline Station & Mean air temperature & Precipitation & Station & Mean air temperature & Precipitation \\
\hline Arak & 0.835 & 0.394 & Zabol & 0.845 & 0.281 \\
\hline Ardebil & 0.812 & 0.149 & Zahedan & 0.840 & 0.216 \\
\hline Oroomiyyeh & 0.843 & 0.283 & Zanjan & 0.840 & 0.282 \\
\hline Esfahan & 0.846 & 0.307 & Sabzevar & 0.842 & 0.337 \\
\hline Aqajari & 0.852 & 0.335 & Sarakhs & 0.831 & 0.380 \\
\hline Omidiyyeh & 0.844 & 0.332 & Saqqez & 0.838 & 0.333 \\
\hline Ahwaz & 0.853 & 0.295 & Semnan & 0.845 & 0.222 \\
\hline Iranshahr & 0.846 & 0.117 & Sanandaj & 0.847 & 0.388 \\
\hline Ilam & 0.852 & 0.427 & Sahand & 0.832 & 0.231 \\
\hline Abadan & 0.851 & 0.288 & Sirjan & 0.850 & 0.220 \\
\hline Abadeh & 0.847 & 0.280 & Shahroud & 0.840 & 0.312 \\
\hline Abali & 0.844 & 0.389 & Esfahan (East) & 0.850 & 0.280 \\
\hline Babolsar & 0.844 & 0.359 & Shahrekord & 0.843 & 0.398 \\
\hline Bojnourd & 0.837 & 0.304 & Shiraz & 0.852 & 0.337 \\
\hline Bam & 0.838 & 0.189 & Tabas & 0.847 & 0.297 \\
\hline Bandar Anzali & 0.841 & 0.353 & Ferdows & 0.842 & 0.380 \\
\hline Bandar Abbas & 0.845 & 0.150 & Fasa & 0.854 & 0.283 \\
\hline Bandar Lengeh & 0.846 & 0.177 & Qazvin & 0.841 & 0.357 \\
\hline Boushehr (Coastal) & 0.847 & 0.395 & Qom & 0.847 & 0.346 \\
\hline Birjand & 0.841 & 0.444 & Qouchan & 0.834 & 0.422 \\
\hline Moqan & 0.843 & 0.047 & Kashan & 0.845 & 0.228 \\
\hline Tabriz & 0.842 & 0.284 & Kerman & 0.846 & 0.238 \\
\hline Torbat Heidariyyeh & 0.842 & 0.383 & Karaj & 0.839 & 0.330 \\
\hline Tehran & 0.842 & 0.362 & Kermanshah & 0.848 & 0.415 \\
\hline Jask & 0.832 & 0.123 & Konarak & 0.824 & 0.129 \\
\hline Boumousa Island & 0.852 & 0.164 & Gorgan & 0.842 & 0.149 \\
\hline Siri Island & 0.842 & 0.195 & Maku & 0.833 & 0.290 \\
\hline kish Island & 0.849 & 0.228 & Maraqeh & 0.843 & 0.323 \\
\hline Jolfa & 0.836 & 0.275 & $\begin{array}{c}\text { Masjed } \\
\text { Soleiman }\end{array}$ & 0.851 & 0.294 \\
\hline Chabahar & 0.817 & 0.085 & Mashhad & 0.836 & 0.378 \\
\hline Khorramabad & 0.849 & 0.423 & Mahabad & 0.840 & 0.366 \\
\hline Khoy & 0.832 & 0.279 & Minab & 0.843 & 0.194 \\
\hline Dezfoul & 0.849 & 0.281 & Nowshahr & 0.844 & 0.324 \\
\hline Doushan Tappeh & 0.840 & 0.378 & Hamedan & 0.838 & 0.383 \\
\hline Dogonbadan & 0.854 & 0.348 & $\begin{array}{l}\text { Hamedan } \\
\text { (Nowjeh) }\end{array}$ & 0.837 & 0.357 \\
\hline Ramsar & 0.844 & 0.296 & Yazd & 0.845 & 0.241 \\
\hline Rasht & 0.834 & 0.316 & & & \\
\hline
\end{tabular}

The results of the primary $\mathrm{M}-\mathrm{K}$ test show that both positive and negative trends can be recognized in mean air temperature series; however, this variable follows an increasing trend at most of the stations (about 86\%) which is not significant at 95\% confidence level. After removing the autocorrelation of the series, the temperature records reveal a downward trend at approximately $73 \%$ of the stations. The monthly behavior of mean air temperature shows a significant upward trend at Ardebil station located in the northwestern Iran. However, after applying the TFPW method, the significance of this increasing trend is removed. The temperature series at Konarak station reveals an antithetical behavior after modification of the $\mathrm{M}-\mathrm{K}$ results; so that after removing serial correlation, the insignificant increasing trend converts to a significant decreasing one. The results 
of the Theil-Sen slope estimator illustrate that the maximum slopes for both negative and positive trends are $-0.003^{\circ} \mathrm{C}$ and $0.009^{\circ} \mathrm{C}$ for Konarak and Ardebil stations, respectively. It is notable that after modifying the results of the M-K test, the trend slopes of most of the series decreases.

Figure 3 illustrates the zoning of mean air temperature trend slopes over Iran. The results of trend slope reveal that mean air temperature series, belonged to a specific climate classification, do not necessarily follow a similar trend. Zoning the trend slopes of mean air temperature records indicates higher warming in the southern Iran compared to the other regions. It is estimated that the upward trend of temperature occurs with lower slopes in the northeast, southwest and southeast parts compared to the other areas. The results of trend identification of mean air temperature show an increasing trend in most of the series which is insignificant at 95\% confidence level. The consistent warming of the study region is confirmed by the results of other studies (Houghton et al., 2001; Modarres and da Silva, 2007; Solomon, 2007; Feizi et al., 2014; Field et al., 2014). Researchers around the world have linked the trend analysis of climate variables to the significant signs of climate change. In this regard, numerous studies have shown that the air temperature follows a consistent increase throughout the world (El-Nesr et al., 2010; Gocic and Trajkovic, 2013; Feizi et al., 2014) that is confirmed by assessment report of Intergovernmental Panel of Climate Change (IPCC) (Houghton et al., 2001; Solomon, 2007; Stocker et al., 2013; Field et al., 2014). Contrary to the temperature records, there is no consistent pattern of a trend (positive or negative) for precipitation series which might be its complex nature compared to temperature series (Raziei et al., 2005b; Modarres and da Silva, 2007; Hosseinzadeh, 2014; Zhao et al., 2015). The upward trend of air temperature depends on various factors such as global warming, increase in greenhouse gases concentration with the origin of human activities, increase of cloud cover over the Earth, and urbanization (Samadi et al., 2013). In general, the existence of an increasing trend in air temperature series will result in more drought condition in the region (Feizi et al., 2014).

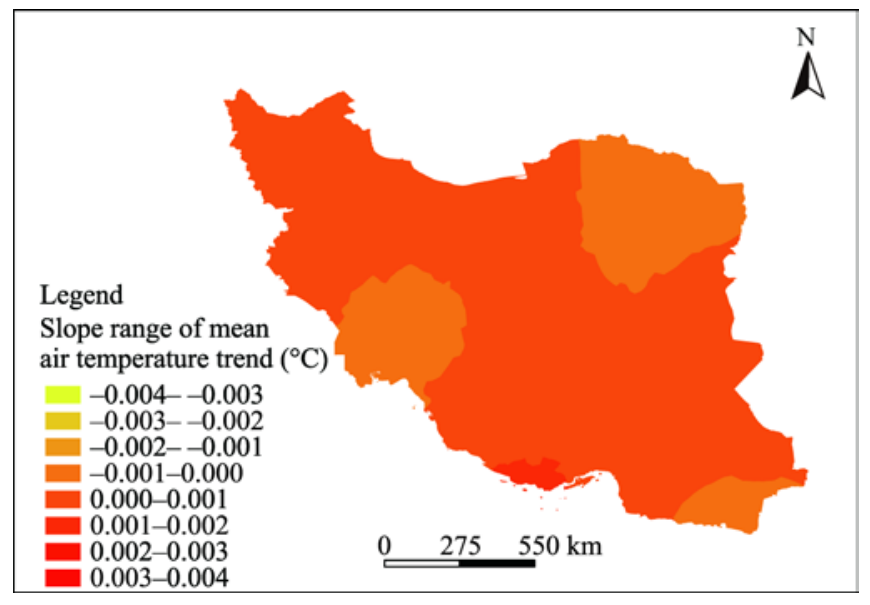

Fig. 3 Slopes of annual mean air temperature trend over Iran from 1985 to 2014

The findings from applying the seasonal $\mathrm{M}-\mathrm{K}$ test indicates a significant increasing trend at most of the stations; however, about $18 \%$ of the series show a significant downward trend. After modification of the test results, the significance of this decreasing trend is eliminated from all stations (except Siri Island). The decreasing trend of some series, e.g., Ilam, Jask, Minab and Sahand stations, changes to an insignificant upward trend. As Figure 4 illustrates, the slopes of trends increase from the southeast to northwest parts of Iran. The seasonal mean air temperature increases with higher slopes in northwestern Iran compared to the other areas. The warming slope decreases as moving gradually towards the central and southeast parts of Iran. This affect the vulnerability of the water resources systems and the safety of the water availability in the region. The increase in temperature, throughout its impacts on the hydrological factors such as evapotranspiration, relative humidity, etc., change the water cycle processes which can cause water resources redistribution (Webb and Nobilis, 2007) and contribute to serious economic, social and political issues. 


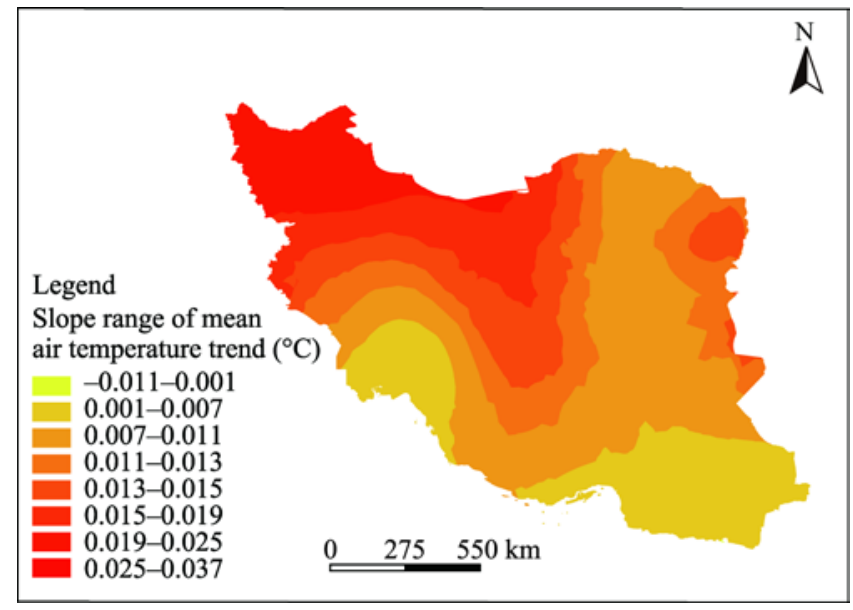

Fig. 4 Slopes of seasonal mean air temperature ${ }^{\circ} \mathrm{C}$ trend over Iran from 1985 to 2014

\subsubsection{Precipitation}

The results of applying the M-K test on precipitation series show a decreasing trend in about $70 \%$ of the selected time series over various climate zones of Iran. This significant increasing trend changes to a downward one after removing the serial correlation factor in some series. According to the statistics of the Theil-Sen slope estimator, the maximum negative and positive trend slopes are -0.016 and $0.012 \mathrm{~mm}$ at Rasht and Ramsar stations, respectively. Removing the auto-correlation of time series causes the changes of maximum negative and positive slopes of the series appeared at Rasht $(-0.016 \mathrm{~mm})$ and Noshahr $(0.012 \mathrm{~mm})$ stations. Both of these stations are located in the very humid climate zone (Fig. 1).

As seen in Figure 5, the observed trend for various precipitation series is not the same in a particular climate zone. In other words, the precipitation series belong to a specific climate classification do not follow the same trend. However, it is observable that the precipitation records of the very humid climate zone, located in the south margins of the Caspian Sea, indicate an upward trend with the higher slopes, while the annual precipitation has a decreasing trend in the east and west margins of the Caspian Sea. The south part of the Urmia Lake, located in northwestern Iran, experiences a decreasing trend with the higher slopes compared to the other regions.

The main findings of this study about the trend of precipitation series are adjusted to the results obtained by Tabari et al. (2011), Some'e et al. (2012), Feizi et al. (2014), and Zohrabi et al. (2014) who investigated precipitation trend throughout different climatic stations over Iran. Similarly, the results obtained about the downward trend of precipitation series in most of the stations in monthly and seasonal scales are in concordance with similar studies in other basins (Masih et al., 2011; Hosseinzadeh, 2014; Fathian et al., 2015). Tabari and Marofi (2011) showed that the variability of precipitation does not follow a single pattern in different parts of Iran and there are both negative and positive trends in different stations and climatic zones. Zohrabi et al. (2014) confirmed that there is a decreasing trend in rainfall data at most of the meteorological stations of Iran during 1968-2008 with increasing temperature. It is expected that rainfall will increase; however, precipitation series indicates a downward trend over arid and semi-arid regions like Iran. The reason for this should be in the geographical condition of Iran. Since Iran is located in the arid and semiarid region, the amount of moisture is low in the atmosphere and therefore, increasing air temperature causes an increase in moisture capacity and consequently, precipitation will decrease (Feizi et al., 2014).

The seasonal M-K test, measured at different climatic zones, shows a significant decreasing trend at $95 \%$ confidence level at most of the stations. After applying the TFPW approach to modify the results of the seasonal trend test, the number of stations which follow a downward trend increases. According to the results of the Theil-Sen slope estimator for seasonal precipitation series the highest slopes of the negative and positive trends were -0.688 and $0.517 \mathrm{~mm}$ at Rasht and Ramsar 
stations, respectively. After modifying the results, the highest amounts of negative and positive trends become -0.322 and $0.204 \mathrm{~mm}$ at Rasht and Maku stations, respectively.

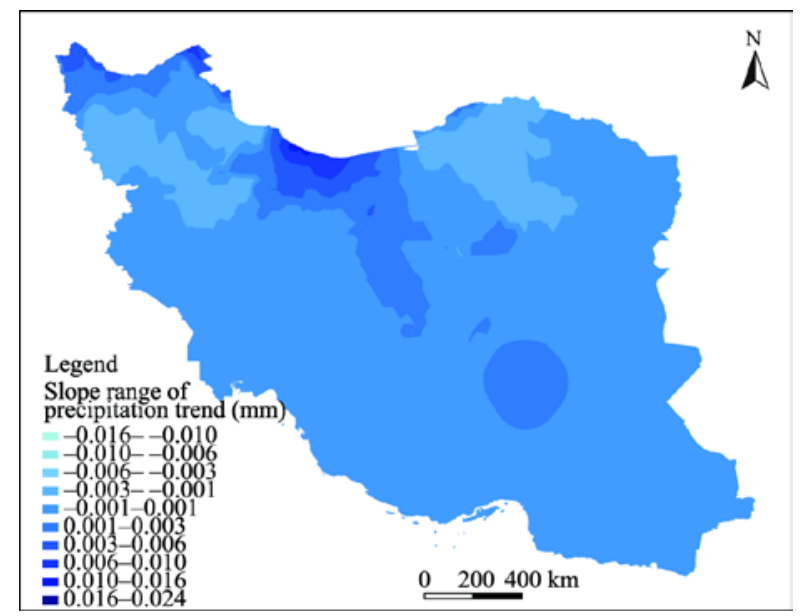

Fig. 5 Slopes of annual precipitation trend over Iran from 1985 to 2014

Analyzing the seasonal trend of precipitation series showed that the slope of the decreasing trends in east and west margins of the Caspian Sea are more than the slopes of negative trend in other studied regions. In various parts of Iran, precipitation variable indicates different trends even when the series belong to a specific climatic zone, indicating the high variability of trend patterns in precipitation series compared to the air temperature ones (Fig. 6).

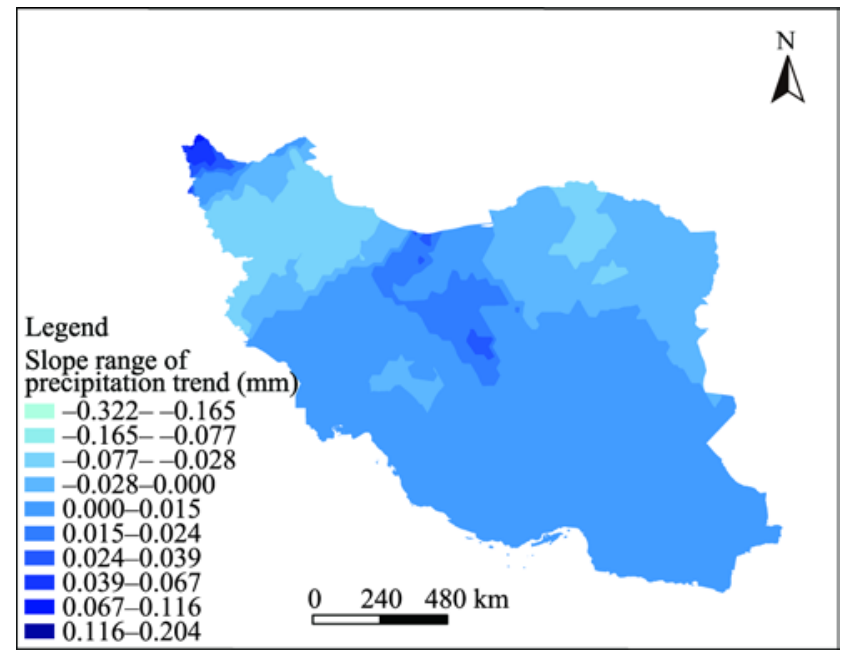

Fig. 6 Slopes of seasonal precipitation trend (mm) over Iran from 1985 to 2014

\subsection{Stationarity analysis}

The results obtained from the DF unit root test and the KPSS stationarity test show that all of the precipitation series, regardless of the climatic zones where they belong, follow a stationary state (Table 2). This matter is justified in relation to the results obtained from the trend test of precipitation series (Section 3.1.2), which follow a decreasing trend in most of the stations. However, this downward trend is not significant at $95 \%$ confidence level. Since significant trend existence is one of the main reasons of time series non-stationarity, the lack of significant trend in precipitation records leads to the stationarity of these series. As it was mentioned previously, the DF test is utilized to determine the presence of unit root in the time series. The outputs of the stationarity analysis revealed that we rejected the null hypothesis, so it can be concluded that the precipitation series is stationary. This matter means that the series can be linear, which shows no significant trend. 
Table 2 Stationarity results of precipitation series at 95\% confidence level

\begin{tabular}{|c|c|c|c|c|c|c|}
\hline \multirow{2}{*}{ Station } & \multicolumn{3}{|c|}{ DF } & \multicolumn{3}{|c|}{ KPSS } \\
\hline & Tau & $P$-value & Hypothesis & Eta & $P$-value & Hypothesis \\
\hline Abadan & -19.022 & $<0.0001$ & $\mathrm{H}_{\mathrm{a}}$ & 0.037 & 0.776 & $\mathrm{H}_{0}$ \\
\hline Abadeh & -18.483 & $<0.0001$ & $\mathrm{H}_{\mathrm{a}}$ & 0.022 & 0.970 & $\mathrm{H}_{0}$ \\
\hline Abali & -18.835 & $<0.0001$ & $\mathrm{H}_{\mathrm{a}}$ & 0.018 & 0.991 & $\mathrm{H}_{0}$ \\
\hline Boumousa Island & -19.379 & $<0.0001$ & $\mathrm{H}_{\mathrm{a}}$ & 0.069 & 0.358 & $\mathrm{H}_{0}$ \\
\hline Ahwaz & -19.404 & $<0.0001$ & $\mathrm{H}_{\mathrm{a}}$ & 0.022 & 0.969 & $\mathrm{H}_{0}$ \\
\hline Arak & -18.579 & $<0.0001$ & $\mathrm{H}_{\mathrm{a}}$ & 0.022 & 0.969 & $\mathrm{H}_{0}$ \\
\hline Ardebil & -18.735 & $<0.0001$ & $\mathrm{H}_{\mathrm{a}}$ & 0.069 & 0.355 & $\mathrm{H}_{0}$ \\
\hline Babolsar & -19.427 & $<0.0001$ & $\mathrm{H}_{\mathrm{a}}$ & 0.013 & 0.999 & $\mathrm{H}_{0}$ \\
\hline Bam & -19.064 & $<0.0001$ & $\mathrm{H}_{\mathrm{a}}$ & 0.066 & 0.384 & $\mathrm{H}_{0}$ \\
\hline Bandar Abbas & -19.451 & $<0.0001$ & $\mathrm{H}_{\mathrm{a}}$ & 0.073 & 0.325 & $\mathrm{H}_{0}$ \\
\hline Bandar Lengeh & -19.388 & $<0.0001$ & $\mathrm{H}_{\mathrm{a}}$ & 0.098 & 0.172 & $\mathrm{H}_{0}$ \\
\hline Bandar Anzali & -19.069 & $<0.0001$ & $\mathrm{H}_{\mathrm{a}}$ & 0.012 & 1.000 & $\mathrm{H}_{0}$ \\
\hline Birjand & -19.094 & $<0.0001$ & $\mathrm{H}_{\mathrm{a}}$ & 0.014 & 0.998 & $\mathrm{H}_{0}$ \\
\hline Bojnourd & -18.978 & $<0.0001$ & $\mathrm{H}_{\mathrm{a}}$ & 0.044 & 0.657 & $\mathrm{H}_{0}$ \\
\hline Boushehr (Coastal) & -18.789 & $<0.0001$ & $\mathrm{H}_{\mathrm{a}}$ & 0.073 & 0.325 & $\mathrm{H}_{0}$ \\
\hline Chabahar & -17.327 & $<0.0001$ & $\mathrm{H}_{\mathrm{a}}$ & 0.058 & 0.476 & $\mathrm{H}_{0}$ \\
\hline Dezfoul & -19.041 & $<0.0001$ & $\mathrm{H}_{\mathrm{a}}$ & 0.081 & 0.264 & $\mathrm{H}_{0}$ \\
\hline Doushan Tappeh & -18.705 & $<0.0001$ & $\mathrm{H}_{\mathrm{a}}$ & 0.036 & 0.791 & $\mathrm{H}_{0}$ \\
\hline Dogonbadan & -18.544 & $<0.0001$ & $\mathrm{H}_{\mathrm{a}}$ & 0.026 & 0.935 & $\mathrm{H}_{0}$ \\
\hline Esfahan (East) & -18.715 & $<0.0001$ & $\mathrm{H}_{\mathrm{a}}$ & 0.020 & 0.979 & $\mathrm{H}_{0}$ \\
\hline Esfahan & -18.764 & $<0.0001$ & $\mathrm{H}_{\mathrm{a}}$ & 0.013 & 0.999 & $\mathrm{H}_{0}$ \\
\hline Fasa & -18.661 & $<0.0001$ & $\mathrm{H}_{\mathrm{a}}$ & 0.028 & 0.900 & $\mathrm{H}_{0}$ \\
\hline Ferdows & -19.457 & $<0.0001$ & $\mathrm{H}_{\mathrm{a}}$ & 0.010 & 1.000 & $\mathrm{H}_{0}$ \\
\hline Qouchan & -18.911 & $<0.0001$ & $\mathrm{H}_{\mathrm{a}}$ & 0.016 & 0.995 & $\mathrm{H}_{0}$ \\
\hline Gorgan & -18.954 & $<0.0001$ & $\mathrm{H}_{\mathrm{a}}$ & 0.04 & 0.731 & $\mathrm{H}_{0}$ \\
\hline Hamedan & -18.628 & $<0.0001$ & $\mathrm{H}_{\mathrm{a}}$ & 0.015 & 0.997 & $\mathrm{H}_{0}$ \\
\hline Hamedan (Nowjeh) & -18.768 & $<0.0001$ & $\mathrm{H}_{\mathrm{a}}$ & 0.030 & 0.878 & $\mathrm{H}_{0}$ \\
\hline Ilam & -18.881 & $<0.0001$ & $\mathrm{H}_{\mathrm{a}}$ & 0.047 & 0.620 & $\mathrm{H}_{0}$ \\
\hline Iranshahr & -18.985 & $<0.0001$ & $\mathrm{H}_{\mathrm{a}}$ & 0.082 & 0.254 & $\mathrm{H}_{0}$ \\
\hline Jask & -19.070 & $<0.0001$ & $\mathrm{H}_{\mathrm{a}}$ & 0.050 & 0.567 & $\mathrm{H}_{0}$ \\
\hline Jolfa & -18.651 & $<0.0001$ & $\mathrm{H}_{\mathrm{a}}$ & 0.063 & 0.410 & $\mathrm{H}_{0}$ \\
\hline Karaj & -18.889 & $<0.0001$ & $\mathrm{H}_{\mathrm{a}}$ & 0.021 & 0.973 & $\mathrm{H}_{0}$ \\
\hline Kashan & -19.426 & $<0.0001$ & $\mathrm{H}_{\mathrm{a}}$ & 0.018 & 0.990 & $\mathrm{H}_{0}$ \\
\hline Kerman & -19.157 & $<0.0001$ & $\mathrm{H}_{\mathrm{a}}$ & 0.039 & 0.745 & $\mathrm{H}_{0}$ \\
\hline Kermanshah & -18.574 & $<0.0001$ & $\mathrm{H}_{\mathrm{a}}$ & 0.013 & 0.999 & $\mathrm{H}_{0}$ \\
\hline Khorramabad & -19.341 & $<0.0001$ & $\mathrm{H}_{\mathrm{a}}$ & 0.021 & 0.974 & $\mathrm{H}_{0}$ \\
\hline Khoy & -18.412 & $<0.0001$ & $\mathrm{H}_{\mathrm{a}}$ & 0.043 & 0.686 & $\mathrm{H}_{0}$ \\
\hline
\end{tabular}


Continued

\begin{tabular}{|c|c|c|c|c|c|c|}
\hline \multirow{2}{*}{ Station } & \multicolumn{3}{|c|}{ DF } & \multicolumn{3}{|c|}{ KPSS } \\
\hline & Tau & $P$-value & Hypothesis & Eta & $P$-value & Hypothesis \\
\hline Kish Island & -19.298 & $<0.0001$ & $\mathrm{H}_{\mathrm{a}}$ & 0.080 & 0.270 & $\mathrm{H}_{0}$ \\
\hline Konarak & -18.964 & $<0.0001$ & $\mathrm{H}_{\mathrm{a}}$ & 0.047 & 0.611 & $\mathrm{H}_{0}$ \\
\hline Mahabad & -19.249 & $<0.0001$ & $\mathrm{H}_{\mathrm{a}}$ & 0.027 & 0.914 & $\mathrm{H}_{0}$ \\
\hline Maku & -18.985 & $<0.0001$ & $\mathrm{H}_{\mathrm{a}}$ & 0.073 & 0.326 & $\mathrm{H}_{0}$ \\
\hline Maraqeh & -19.104 & $<0.0001$ & $\mathrm{H}_{\mathrm{a}}$ & 0.031 & 0.860 & $\mathrm{H}_{0}$ \\
\hline Mashhad & -19.948 & $<0.0001$ & $\mathrm{H}_{\mathrm{a}}$ & 0.013 & 0.999 & $\mathrm{H}_{0}$ \\
\hline Masjed Soleiman & -19.406 & $<0.0001$ & $\mathrm{H}_{\mathrm{a}}$ & 0.019 & 0.987 & $\mathrm{H}_{0}$ \\
\hline Minab & -19.460 & $<0.0001$ & $\mathrm{H}_{\mathrm{a}}$ & 0.050 & 0.575 & $\mathrm{H}_{0}$ \\
\hline Nowshahr & -19.122 & $<0.0001$ & $\mathrm{H}_{\mathrm{a}}$ & 0.010 & 1.000 & $\mathrm{H}_{0}$ \\
\hline Aqajari & -18.919 & $<0.0001$ & $\mathrm{H}_{\mathrm{a}}$ & 0.041 & 0.706 & $\mathrm{H}_{0}$ \\
\hline Omidiyyeh & -18.648 & $<0.0001$ & $\mathrm{H}_{\mathrm{a}}$ & 0.042 & 0.700 & $\mathrm{H}_{0}$ \\
\hline Oroomiyyeh & -18.620 & $<0.0001$ & $\mathrm{H}_{\mathrm{a}}$ & 0.058 & 0.470 & $\mathrm{H}_{0}$ \\
\hline Moqan & -18.018 & $<0.0001$ & $\mathrm{H}_{\mathrm{a}}$ & 0.040 & 0.729 & $\mathrm{H}_{0}$ \\
\hline Qazvin & -18.018 & $<0.0001$ & $\mathrm{H}_{\mathrm{a}}$ & 0.015 & 0.997 & $\mathrm{H}_{0}$ \\
\hline Qom & -18.838 & $<0.0001$ & $\mathrm{H}_{\mathrm{a}}$ & 0.060 & 0.448 & $\mathrm{H}_{0}$ \\
\hline Ramsar & -18.329 & $<0.0001$ & $\mathrm{H}_{\mathrm{a}}$ & 0.018 & 0.991 & $\mathrm{H}_{0}$ \\
\hline Rasht & -18.842 & $<0.0001$ & $\mathrm{H}_{\mathrm{a}}$ & 0.016 & 0.996 & $\mathrm{H}_{0}$ \\
\hline Sabzevar & -19.386 & $<0.0001$ & $\mathrm{H}_{\mathrm{a}}$ & 0.012 & 1.000 & $\mathrm{H}_{0}$ \\
\hline Sahand & -17.720 & $<0.0001$ & $\mathrm{H}_{\mathrm{a}}$ & 0.136 & 0.069 & $\mathrm{H}_{0}$ \\
\hline Sanandaj & -18.914 & $<0.0001$ & $\mathrm{H}_{\mathrm{a}}$ & 0.018 & 0.991 & $\mathrm{H}_{0}$ \\
\hline Saqqez & -19.602 & $<0.0001$ & $\mathrm{H}_{\mathrm{a}}$ & 0.029 & 0.894 & $\mathrm{H}_{0}$ \\
\hline Sarakhs & -19.714 & $<0.0001$ & $\mathrm{H}_{\mathrm{a}}$ & 0.023 & 0.957 & $\mathrm{H}_{0}$ \\
\hline Semnan & -19.254 & $<0.0001$ & $\mathrm{H}_{\mathrm{a}}$ & 0.028 & 0.906 & $\mathrm{H}_{0}$ \\
\hline Shahrekord & -18.823 & $<0.0001$ & $\mathrm{H}_{\mathrm{a}}$ & 0.013 & 0.999 & $\mathrm{H}_{0}$ \\
\hline Shahroud & -19.415 & $<0.0001$ & $\mathrm{H}_{\mathrm{a}}$ & 0.030 & 0.879 & $\mathrm{H}_{0}$ \\
\hline Shiraz & -18.677 & $<0.0001$ & $\mathrm{H}_{\mathrm{a}}$ & 0.029 & 0.898 & $\mathrm{H}_{0}$ \\
\hline Siri Island & -19.515 & $<0.0001$ & $\mathrm{H}_{\mathrm{a}}$ & 0.093 & 0.190 & $\mathrm{H}_{0}$ \\
\hline Sirjan & -19.157 & $<0.0001$ & $\mathrm{H}_{\mathrm{a}}$ & 0.067 & 0.373 & $\mathrm{H}_{0}$ \\
\hline Tabas & -19.332 & $<0.0001$ & $\mathrm{H}_{\mathrm{a}}$ & 0.014 & 0.998 & $\mathrm{H}_{0}$ \\
\hline Tabriz & -18.502 & $<0.0001$ & $\mathrm{H}_{\mathrm{a}}$ & 0.019 & 0.984 & $\mathrm{H}_{0}$ \\
\hline Tehran & -18.997 & $<0.0001$ & $\mathrm{H}_{\mathrm{a}}$ & 0.026 & 0.929 & $\mathrm{H}_{0}$ \\
\hline Torbat Heidariyyeh & -19.854 & $<0.0001$ & $\mathrm{H}_{\mathrm{a}}$ & 0.042 & 0.699 & $\mathrm{H}_{0}$ \\
\hline Yazd & -18.902 & $<0.0001$ & $\mathrm{H}_{\mathrm{a}}$ & 0.011 & 1.000 & $\mathrm{H}_{0}$ \\
\hline Zabol & -19.591 & $<0.0001$ & $\mathrm{H}_{\mathrm{a}}$ & 0.063 & 0.418 & $\mathrm{H}_{0}$ \\
\hline Zahedan & -19.251 & $<0.0001$ & $\mathrm{H}_{\mathrm{a}}$ & 0.057 & 0.486 & $\mathrm{H}_{0}$ \\
\hline Zanjan & -18.679 & $<0.0001$ & $\mathrm{H}_{\mathrm{a}}$ & 0.027 & 0.920 & $\mathrm{H}_{0}$ \\
\hline
\end{tabular}

Note: DF, Dickey-Fuller; KPSS, Kwiatkowski-Phillips-Schmidt-Shin. Tau and Eta are the test statistics of DF and KPSS, respectively. 
As shown in Table 4, the mean air temperature series of different climatic zones over Iran are stationary at 95\% confidence level. This matter can be rationalized due to the absence of a significant trend. However, the results of the KPSS test results, the mean air temperature series of Konarak station (south of Iran) illustrates non-stationarity at 95\% confidence level. As shown in Section 3.1.1, the air temperature records of Konarak station present a significant decreasing trend even after removing the serial correlation of the series and modification of the primary trend results. Considering that the existence of a significant trend is one of the major factors in creating nonstationarity in the time series, the non-stationarity of the mean air temperature series of Konarak station is observable in association with the significant decreasing trend of the records. There are different types of stationarity; however, in the current study, the trend stationarity is investigated to compare and interpret the relationship between the trend and stationarity of the time series. A series that has no unit root but indicates a tend is referred to as a trend stationary series. It is shown that the KPSS test classifies a time series as stationary on the absence of unit root. This means that the series can be trend stationary as it is illustrated about most of the mean air temperature and also all of the precipitation series in the study region. As mentioned previously, non-stationarity can happen as a gradual trend or a sudden shift, so in the current study, the emphasis is on trends and sudden changes. Analyzing the relationships among the stationarity, trend and seasonality of climatic variables can provide useful hints for decreasing the uncertainty of climatic and hydrological simulations and consequently adopting better water resources management strategies in various climatic zones of Iran (Wu et al., 2007).

Table 4 Stationarity results of mean air temperature series at 95\% confidence level

\begin{tabular}{|c|c|c|c|c|c|c|}
\hline \multirow{2}{*}{ Station } & \multicolumn{3}{|c|}{ DF } & \multicolumn{3}{|c|}{ KPSS } \\
\hline & Tau & $P$-value & Hypothesis & Eta & $P$-value & Hypothesis \\
\hline Abadan & -6.728 & $<0.0001$ & $\mathrm{H}_{\mathrm{a}}$ & 0.013 & 0.999 & $\mathrm{H}_{0}$ \\
\hline Abadeh & -5.697 & $<0.0001$ & $\mathrm{H}_{\mathrm{a}}$ & 0.022 & 0.968 & $\mathrm{H}_{0}$ \\
\hline Abali & -8.147 & $<0.0001$ & $\mathrm{H}_{\mathrm{a}}$ & 0.016 & 0.995 & $\mathrm{H}_{0}$ \\
\hline Boumousa Island & -6.882 & $<0.0001$ & $\mathrm{H}_{\mathrm{a}}$ & 0.013 & 0.999 & $\mathrm{H}_{0}$ \\
\hline Ahwaz & -6.487 & $<0.0001$ & $\mathrm{H}_{\mathrm{a}}$ & 0.013 & 0.999 & $\mathrm{H}_{0}$ \\
\hline Arak & -10.190 & $<0.0001$ & $\mathrm{H}_{\mathrm{a}}$ & 0.011 & 1.000 & $\mathrm{H}_{0}$ \\
\hline Ardebil & -10.704 & $<0.0001$ & $\mathrm{H}_{\mathrm{a}}$ & 0.013 & 0.999 & $\mathrm{H}_{0}$ \\
\hline Babolsar & -7.903 & $<0.0001$ & $\mathrm{H}_{\mathrm{a}}$ & 0.012 & 1.000 & $\mathrm{H}_{0}$ \\
\hline Bam & -8.180 & $<0.0001$ & $\mathrm{H}_{\mathrm{a}}$ & 0.014 & 0.999 & $\mathrm{H}_{0}$ \\
\hline Bandar Abbas & -7.134 & $<0.0001$ & $\mathrm{H}_{\mathrm{a}}$ & 0.013 & 0.999 & $\mathrm{H}_{0}$ \\
\hline Bandar Lengeh & -7.256 & $<0.0001$ & $\mathrm{H}_{\mathrm{a}}$ & 0.017 & 0.992 & $\mathrm{H}_{0}$ \\
\hline Bandar Anzali & -8.273 & $<0.0001$ & $\mathrm{H}_{\mathrm{a}}$ & 0.012 & 1.000 & $\mathrm{H}_{0}$ \\
\hline Birjand & -8.070 & $<0.0001$ & $\mathrm{H}_{\mathrm{a}}$ & 0.013 & 0.999 & $\mathrm{H}_{0}$ \\
\hline Bojnourd & -8.572 & $<0.0001$ & $\mathrm{H}_{\mathrm{a}}$ & 0.013 & 0.999 & $\mathrm{H}_{0}$ \\
\hline Boushehr (Coastal) & -7.164 & $<0.0001$ & $\mathrm{H}_{\mathrm{a}}$ & 0.012 & 1.000 & $\mathrm{H}_{0}$ \\
\hline Chabahar & -8.708 & $<0.0001$ & $\mathrm{H}_{\mathrm{a}}$ & 0.012 & 1.000 & $\mathrm{H}_{0}$ \\
\hline Dezfoul & -6.949 & $<0.0001$ & $\mathrm{H}_{\mathrm{a}}$ & 0.119 & 0.101 & $\mathrm{H}_{0}$ \\
\hline Doushan Tappeh & -7.880 & $<0.0001$ & $\mathrm{H}_{\mathrm{a}}$ & 0.041 & 0.714 & $\mathrm{H}_{0}$ \\
\hline Dogonbadan & -8.050 & $<0.0001$ & $\mathrm{H}_{\mathrm{a}}$ & 0.017 & 0.993 & $\mathrm{H}_{0}$ \\
\hline Esfahan (East) & -6.944 & $<0.0001$ & $\mathrm{H}_{\mathrm{a}}$ & 0.013 & 0.999 & $\mathrm{H}_{0}$ \\
\hline Esfahan & -7.621 & $<0.0001$ & $\mathrm{H}_{\mathrm{a}}$ & 0.013 & 0.999 & $\mathrm{H}_{0}$ \\
\hline Fasa & -9.051 & $<0.0001$ & $\mathrm{H}_{\mathrm{a}}$ & 0.011 & 1.000 & $\mathrm{H}_{0}$ \\
\hline Ferdows & -8.107 & $<0.0001$ & $\mathrm{H}_{\mathrm{a}}$ & 0.014 & 0.998 & $\mathrm{H}_{0}$ \\
\hline Qouchan & -8.804 & $<0.0001$ & $\mathrm{H}_{\mathrm{a}}$ & 0.012 & 1.000 & $\mathrm{H}_{0}$ \\
\hline Gorgan & -8.063 & $<0.0001$ & На & 0.013 & 0.999 & $\mathrm{H}_{0}$ \\
\hline Hamedan & -8.232 & $<0.0001$ & $\mathrm{H}_{\mathrm{a}}$ & 0.011 & 1.000 & $\mathrm{H}_{0}$ \\
\hline
\end{tabular}


Continued

\begin{tabular}{|c|c|c|c|c|c|c|}
\hline \multirow{2}{*}{ Station } & \multicolumn{3}{|c|}{ DF } & \multicolumn{3}{|c|}{ KPSS } \\
\hline & Tau & $P$-value & Tau & $P$-value & Tau & $P$-value \\
\hline Hamedan (Nowjeh) & -8.160 & $<0.0001$ & $\mathrm{H}_{\mathrm{a}}$ & 0.020 & 0.979 & $\mathrm{H}_{0}$ \\
\hline Ilam & -7.377 & $<0.0001$ & $\mathrm{H}_{\mathrm{a}}$ & 0.016 & 0.995 & $\mathrm{H}_{0}$ \\
\hline Iranshahr & -7.172 & $<0.0001$ & $\mathrm{H}_{\mathrm{a}}$ & 0.015 & 0.997 & $\mathrm{H}_{0}$ \\
\hline Jask & -8.120 & $<0.0001$ & $\mathrm{H}_{\mathrm{a}}$ & 0.013 & 0.999 & $\mathrm{H}_{0}$ \\
\hline Jolfa & -8.371 & $<0.0001$ & $\mathrm{H}_{\mathrm{a}}$ & 0.012 & 1.000 & $\mathrm{H}_{0}$ \\
\hline Karaj & -8.333 & $<0.0001$ & $\mathrm{H}_{\mathrm{a}}$ & 0.015 & 0.998 & $\mathrm{H}_{0}$ \\
\hline Kashan & -7.470 & $<0.0001$ & $\mathrm{H}_{\mathrm{a}}$ & 0.013 & 0.999 & $\mathrm{H}_{0}$ \\
\hline Kerman & -7.510 & $<0.0001$ & $\mathrm{H}_{\mathrm{a}}$ & 0.013 & 0.999 & $\mathrm{H}_{0}$ \\
\hline Kermanshah & -7.201 & $<0.0001$ & $\mathrm{H}_{\mathrm{a}}$ & 0.012 & 1.000 & $\mathrm{H}_{0}$ \\
\hline Khorramabad & -6.840 & $<0.0001$ & $\mathrm{H}_{\mathrm{a}}$ & 0.013 & 0.999 & $\mathrm{H}_{0}$ \\
\hline Khoy & -8.877 & $<0.0001$ & $\mathrm{H}_{\mathrm{a}}$ & 0.012 & 1.000 & $\mathrm{H}_{0}$ \\
\hline Kish Island & -7.112 & $<0.0001$ & $\mathrm{H}_{\mathrm{a}}$ & 0.013 & 0.999 & $\mathrm{H}_{\mathrm{a}}$ \\
\hline Konarak & -8.865 & $<0.0001$ & $\mathrm{H}_{\mathrm{a}}$ & 0.266 & 0.003 & $\mathrm{H}_{0}$ \\
\hline Mahabad & -8.185 & $<0.0001$ & $\mathrm{H}_{\mathrm{a}}$ & 0.013 & 0.999 & $\mathrm{H}_{0}$ \\
\hline Maku & -8.773 & $<0.0001$ & $\mathrm{H}_{\mathrm{a}}$ & 0.012 & 1.000 & $\mathrm{H}_{0}$ \\
\hline Maraqeh & -7.876 & $<0.0001$ & $\mathrm{H}_{\mathrm{a}}$ & 0.012 & 0.999 & $\mathrm{H}_{0}$ \\
\hline Mashhad & -8.785 & $<0.0001$ & $\mathrm{H}_{\mathrm{a}}$ & 0.012 & 1.000 & $\mathrm{H}_{0}$ \\
\hline Masjed Soleiman & -7.454 & $<0.0001$ & $\mathrm{H}_{\mathrm{a}}$ & 0.013 & 0.999 & $\mathrm{H}_{0}$ \\
\hline Minab & -7.545 & $<0.0001$ & $\mathrm{H}_{\mathrm{a}}$ & 0.014 & 0.998 & $\mathrm{H}_{0}$ \\
\hline Nowshahr & -7.948 & $<0.0001$ & $\mathrm{H}_{\mathrm{a}}$ & 0.014 & 0.999 & $\mathrm{H}_{0}$ \\
\hline Aqajari & -6.793 & $<0.0001$ & $\mathrm{H}_{\mathrm{a}}$ & 0.014 & 0.999 & $\mathrm{H}_{0}$ \\
\hline Omidiyyeh & -6.810 & $<0.0001$ & $\mathrm{H}_{\mathrm{a}}$ & 0.099 & 0.166 & $\mathrm{H}_{0}$ \\
\hline Oroomiyyeh & -7.718 & $<0.0001$ & $\mathrm{H}_{\mathrm{a}}$ & 0.013 & 0.999 & $\mathrm{H}_{0}$ \\
\hline Moqan & -7.923 & $<0.0001$ & $\mathrm{H}_{\mathrm{a}}$ & 0.013 & 0.999 & $\mathrm{H}_{0}$ \\
\hline Qazvin & -7.992 & $<0.0001$ & $\mathrm{H}_{\mathrm{a}}$ & 0.012 & 0.999 & $\mathrm{H}_{0}$ \\
\hline Qom & -7.28 & $<0.0001$ & $\mathrm{H}_{\mathrm{a}}$ & 0.016 & 0.995 & $\mathrm{H}_{0}$ \\
\hline Ramsar & -7.945 & $<0.0001$ & $\mathrm{H}_{\mathrm{a}}$ & 0.012 & 1.000 & $\mathrm{H}_{0}$ \\
\hline Rasht & -9.003 & $<0.0001$ & $\mathrm{H}_{\mathrm{a}}$ & 0.012 & 1.000 & $\mathrm{H}_{0}$ \\
\hline Sabzevar & -7.932 & $<0.0001$ & $\mathrm{H}_{\mathrm{a}}$ & 0.012 & 1.000 & $\mathrm{H}_{0}$ \\
\hline Sahand & -8.888 & $<0.0001$ & $\mathrm{H}_{\mathrm{a}}$ & 0.044 & 0.660 & $\mathrm{H}_{0}$ \\
\hline Sanandaj & -7.320 & $<0.0001$ & $\mathrm{H}_{\mathrm{a}}$ & 0.012 & 1.000 & $\mathrm{H}_{0}$ \\
\hline Saqqez & -8.494 & $<0.0001$ & $\mathrm{H}_{\mathrm{a}}$ & 0.017 & 0.992 & $\mathrm{H}_{0}$ \\
\hline Sarakhs & -9.222 & $<0.0001$ & $\mathrm{H}_{\mathrm{a}}$ & 0.011 & 1.000 & $\mathrm{H}_{0}$ \\
\hline Semnan & -7.537 & $<0.0001$ & $\mathrm{H}_{\mathrm{a}}$ & 0.012 & 0.999 & $\mathrm{H}_{0}$ \\
\hline Shahrekord & -7.714 & $<0.0001$ & $\mathrm{H}_{\mathrm{a}}$ & 0.011 & 1.000 & $\mathrm{H}_{0}$ \\
\hline Shahroud & -8.102 & $<0.0001$ & $\mathrm{H}_{\mathrm{a}}$ & 0.013 & 0.999 & $\mathrm{H}_{0}$ \\
\hline Shiraz & -8.998 & $<0.0001$ & $\mathrm{H}_{\mathrm{a}}$ & 0.011 & 1.000 & $\mathrm{H}_{0}$ \\
\hline Siri Island & -12.748 & $<0.0001$ & $\mathrm{H}_{\mathrm{a}}$ & 0.039 & 0.735 & $\mathrm{H}_{0}$ \\
\hline Sirjan & -7.032 & $<0.0001$ & $\mathrm{H}_{\mathrm{a}}$ & 0.014 & 0.998 & $\mathrm{H}_{0}$ \\
\hline Tabas & -7.302 & $<0.0001$ & $\mathrm{H}_{\mathrm{a}}$ & 0.013 & 0.999 & $\mathrm{H}_{0}$ \\
\hline Tabriz & -7.897 & $<0.0001$ & $\mathrm{H}_{\mathrm{a}}$ & 0.012 & 0.999 & $\mathrm{H}_{0}$ \\
\hline Tehran & -7.929 & $<0.0001$ & $\mathrm{H}_{\mathrm{a}}$ & 0.013 & 0.999 & $\mathrm{H}_{0}$ \\
\hline Torbat Heidariyyeh & -8.057 & $<0.0001$ & $\mathrm{H}_{\mathrm{a}}$ & 0.013 & 0.999 & $\mathrm{H}_{0}$ \\
\hline Yazd & -7.599 & $<0.0001$ & $\mathrm{H}_{\mathrm{a}}$ & 0.012 & 1.000 & $\mathrm{H}_{0}$ \\
\hline Zabol & -7.558 & $<0.0001$ & $\mathrm{H}_{\mathrm{a}}$ & 0.016 & 0.995 & $\mathrm{H}_{0}$ \\
\hline Zahedan & -8.005 & $<0.0001$ & $\mathrm{H}_{\mathrm{a}}$ & 0.015 & 0.997 & $\mathrm{H}_{0}$ \\
\hline Zanjan & -8.153 & $<0.0001$ & $\mathrm{H}_{\mathrm{a}}$ & 0.012 & 0.999 & $\mathrm{H}_{0}$ \\
\hline
\end{tabular}




\section{Conclusions}

The pressure on natural resources has become a widespread problem in arid and semi-arid regions. In recent decades, this worldwide issue has been intensified as the impacts of climate change have aggregated by the high population growth rate and mismanagement of resources in these areas. Analyzing the stationarity and trends of climatic variables is important for adopting appropriate water resources management strategies, particularly in arid and semi-arid regions (Kahya and Kalayc1, 2004; Kumar et al., 2009). In this study, the last 30-a (1985-2014) spatiotemporal behavior of climate series were discussed according to the monthly precipitation and mean air temperature time series, which belonged to the 73 climate stations of 9 distinct climatic zones over Iran. The classic and seasonal M-K tests were applied for identification of monotonic and seasonal trends of climatic series. Moreover, a pre-whitening approach, namely TFPW, was utilized as a preprocessing approach for removing the effects of auto-correlation of time series on the trend and stationarity test results. Furthermore, KPSS and DF approaches were used to analyze the stationarity of precipitation and mean air temperature time series and the influences of stationarity and non-stationarity of series on trend detection. The main conclusions of the current study are as follows:

- The temperature changes reveal a warming trend since 1985. The mean air temperature warmed more from the northwest to central parts of Iran from 1985 to 2014. This upward trend in mean air temperature, especially in arid and semi-arid zones, has caused different challenges to the population of the region. The most problematic challenges can be seen in the regions where remarkable precipitation decrease is observed with increasing temperature. This is mainly observed in the central parts of Iran with high precipitation variability that makes these parts prone to drought events. The results of mean air temperature trend analysis show that climate may become warmer in future if this increasing trend for air temperature continues.

- The precipitation series follow a downward trend in the majority of the stations over various climatic zones in Iran. However, this downward trend is not significant at $95 \%$ confidence level. The precipitation records reveal a non-significant decreasing trend in seasonal scales.

- Spatial patterns of trend and seasonality of precipitation and mean air temperature show that the northwest parts of Iran and marginal areas of the Caspian Sea are more vulnerable to the changing climate with respect to the precipitation shortfalls and warming temperature.

- The stationarity of climatic series has impacts on their trends as the non-stationarity of time series results in their significant trend. The investigation of the average seasonal trend of precipitation and mean air temperature reveal decreasing and increasing trend over the study region, respectively.

- This study developed the first time comprehensive picture of the influence of stationarity on the trends of climatic series. This matter was conducted with applying a corrective preprocessing approach for the trend tests over various climatic zones of Iran. The main conclusions of this study not only suggests the importance and necessity of analyzing the influence of non-stationarity and auto-correlation of climatic series on their trend and seasonality, which is important for providing a comprehensive outlook of the regional climate change in different climatic zones, but also help to improve the practices to cope with the changing condition in a more efficient way. Reviewing and comparing the results of different methods of correction of serial correlation effects with the results corrected by TFPW test in the present study is rewarding and provide useful information to assess the uncertainty that arises from different sources involved in the modelling procedures and consequently lead in more accurate projection results. 


\section{Acknowledgements}

This research was supported by the Iran National Science Foundation (9583187).

\section{References}

Abbaspour M, Sabetraftar A .2005. Review of cycles and indices of drought and their effect on water resources, ecological, biological, agricultural, social and economical issues in Iran. International Journal of Environmental Studies, 62(6): 709-724.

Ahmad I, Tang D, Wang T, et al. 2015. Precipitation trends over time using Mann-Kendall and Spearman's rho tests in Swat River Basin, Pakistan. Advances in Meteorology, 2015(2): 1-15.

Alijani B. 1995. Climate of Iran. Tehran: Piame Noor University, 21-35.

Amiri M, Eslamian S. 2010. Investigation of climate change in Iran. Journal of Environmental Sciences and Technology, 3: 208216.

Aziz O I A, Burn D H. 2006. Trends and variability in the hydrological regime of the Mackenzie River Basin. Journal of Hydrology, 319(1-4): 282-294.

Blain G C. 2015. The influence of nonlinear trends on the power of the trend-free pre-whitening approach. Acta Scientiarum Agronomy, 37(1): 21-28.

Brockwell P J, Davis R A. 1991. Time Series: Theory and Methods. New York: Springer Science and Business Media.

Burn D H, Elnur M A H. 2002. Detection of hydrologic trends and variability. Journal of Hydrology, 255(1-4): 107-122.

Burn D H, Cunderlik J M, Pietroniro A. 2004. Hydrological trends and variability in the Liard River basin. Hydrological Sciences Journal, 49(1): 53-67.

Delju A, Ceylan A, Piguet E, et al. 2013. Observed climate variability and change in Urmia Lake Basin, Iran. Theoretical and Applied Climatology, 111: 285-296.

Duan W, He B, Sahu N, et al. 2017. Spatiotemporal variability of Hokkaido's seasonal precipitation in recent decades and connection to water vapour flux. International Journal of Climatology, 37(9): 3660-3673.

Duan W, Hanasaki N, Shiogama H, et al. 2019. Evaluation and future projection of Chinese precipitation extremes using large ensemble high-resolution climate simulations. Journal of Climate, 32(8): 2169-2183.

El-Nesr M N, Abu-Zreig M M, Alazba A A. 2010. Temperature trends and distribution in the Arabian Peninsula. American Journal of Environmental Sciences, 6(2): 191-203.

Fathian F, Morid S, Kahya E. 2015. Identification of trends in hydrological and climatic variables in Urmia Lake basin, Iran. Theoretical and Applied Climatology, 119: 443-464.

Feizi V, Mollashahi M, Farajzadeh M, et al. 2014. Spatial and temporal trend analysis of temperature and precipitation in Iran. Ecopersia, 2: 727-742.

Field C B, Barros V R. 2014. Climate Change 2014: Impacts, Adaptation, and Vulnerability. Part A: Global and Sectoral Aspects. Working Group II Contribution to the Fifth Assessment Report of the Intergovernmental Panel on Climate Change. Cambridge: Cambridge University Press.

Gocic M, Trajkovic S. 2013. Analysis of changes in meteorological variables using Mann-Kendall and Sen's slope estimator statistical tests in Serbia. Global and Planetary Change, 100: 172-182.

Golian S, Mazdiyasni O, AghaKouchak A. 2015. Trends in meteorological and agricultural droughts in Iran. Theoretical and Applied Climatology, 119: 679-688.

Hamed K. 2009. Enhancing the effectiveness of prewhitening in trend analysis of hydrologic data. Journal of Hydrology, 368(14): $143-155$.

Hirsch R M, Alexander R B, Smith R A. 1991. Selection of methods for the detection and estimation of trends in water quality. Water Resources Research, 27(5): 803-813.

Hirsch R M, Slack J R, Smith R A. 1982. Techniques of trend analysis for monthly water quality data. Water Resources Research, 18(1): 107-121.

Hosseinzadeh T P. 2014. Iranian rainfall series analysis by means of nonparametric tests. Theoretical and applied climatology, 116: 597-607.

Houghton J T, Albritton D L, Meira F, et al. 2001. Technical summary of working group 1. Cambridge: Cambridge University Press.

Kahya E, Kalaycı S. 2004. Trend analysis of streamflow in Turkey. Journal of Hydrology, 289(1-4): 128-144.

Kendall M. 1975. Multivariate analysis. Charles Griffin.

Kumar S, Merwade V, Kam J, et al. 2009. Streamflow trends in Indiana: effects of long term persistence, precipitation and 
subsurface drains. Journal of Hydrology, 374(1-2): 171-183.

Kwiatkowski D, Phillips P C, Schmidt P, et al. 1992. Testing the null hypothesis of stationarity against the alternative of a unit root: How sure are we that economic time series have a unit root? Journal of Econometrics, 54(1-3): 159-178.

Libanda B, Zheng M, Ngonga C. 2019. Spatial and temporal patterns of drought in Zambia. Journal of Arid Land, 11(2): 180191.

Mann H B. 1945. Nonparametric tests against trend. Econometrica: Journal of the Econometric Society, 13: 245-259.

Masih I, Uhlenbrook S, Maskey S, et al. 2011. Streamflow trends and climate linkages in the Zagros Mountains, Iran. Climatic Change, 104: 317-338.

Modarres R, da Silva V. 2007. Rainfall trends in arid and semi-arid regions of Iran. Journal of Arid Environments, 70(2): 344355.

Parey S, Hoang T, Dacunha-Castelle D. 2019. Future high-temperature extremes and stationarity. Natural Hazards, 98: 11151134.

Peel M C, Finlayson B L, McMahon T A. 2007. Updated world map of the Köppen-Geiger climate classification. Hydrology and Earth System Sciences Discussions, 4: 439-473.

Raziei T, Arasteh P D, Saghafian B. 2005a. Annual rainfall trend in arid and semi-arid regions of central and eastern Iran. Water and Wastewater, 54: 73-81.

Raziei T, Arasteh P D, Saghafian B. 2005b. Annual rainfall trend in arid and semi-arid regions of Iran. In: ICID $21^{\text {st }}$ European regional conference, 15-19.

Sahoo D, Smith P. 2009. Hydroclimatic trend detection in a rapidly urbanizing semi-arid and coastal river basin. Journal of Hydrology, 367(3-4): 217-227.

Samadi S, Carbone G J, Mahdavi M, et al. 2013. Statistical downscaling of river runoff in a semi-arid catchment. Water Resources Management, 27: 117-136.

Shadmani M, Marofi S, Roknian M. 2012. Trend analysis in reference evapotranspiration using Mann-Kendall and Spearman's Rho tests in arid regions of Iran. Water Resources Management, 26: 211-224.

Shao Q, Li M. 2011. A new trend analysis for seasonal time series with consideration of data dependence. Journal of Hydrology, 396(1-2): 104-112.

Solomon S, Qing D, Manning M, et al. 2007. Climate change 2007: The Physical Science Basis. Working group I Contribution to the Fourth Assessment Report of the Intergovernmental Panel on Climate Change. Cambridge: Cambridge University Press.

Some'e B S, Ezani A, Tabari H. 2012. Spatiotemporal trends and change point of precipitation in Iran. Atmospheric Research, 113: $1-12$.

Stocker T F, Qin D, Plattner G-K, et al. 2013. Climate Change 2013: The Physical Science Basis. Contribution of Working Group I to the Fifth Assessment Report of the Intergovernmental Panel on Climate Change. Cambridge: Cambridge University Press, 1535.

Sun F, Roderick M L, Farquhar G D. 2018. Rainfall statistics, stationarity, and climate change. Proceedings of the National Academy of Sciences, 115(10): 2305-2310.

Tabari H, Marofi S. 2011. Changes of pan evaporation in the west of Iran. Water Resources Management, 25: 97-111.

Tabari H, Marofi S, Aeini A, et al.2011. Trend analysis of reference evapotranspiration in the western half of Iran. Agricultural and Forest Meteorology, 151(2): 128-136.

Toller M, Santos T, Kern R. 2019. SAZED: parameter-free domain-agnostic season length estimation in time series data. Data Mining and Knowledge Discovery, 33: 1775-1798.

Um M-J, Heo J-H, Markus M, et al. 2018. Performance evaluation of four statistical tests for trend and non-stationarity and assessment of observed and projected annual maximum precipitation series in Major United States cities. Water Resources Management, 32: 913-933.

Unal Y S, Deniz A, Toros H, et al. 2012. Temporal and spatial patterns of precipitation variability for annual, wet, and dry seasons in Turkey. International Journal of Climatology, 32(3): 392-405.

Wang W, van Gelder P, Vrijling J. 2005. Trend and stationarity analysis for streamflow processes of rivers in Western Europe in the 20th century. In: Proceedings: IWA International Conference on Water Economics, Statistics, and Finance Rethymno, Greece, 8-10.

Webb B W, Nobilis F. 2007. Long-term changes in river temperature and the influence of climatic and hydrological factors. Hydrological Sciences Journal, 52(1): 74-85.

Wu Z, Huang N E, Long S R, et al. 2007. On the trend, detrending, and variability of nonlinear and nonstationary time series. Proceedings of the National Academy of Sciences, 104(38): 14889-14894.

Xu Z, Takeuchi K, Ishidaira H. 2003. Monotonic trend and step changes in Japanese precipitation. Journal of Hydrology, 279(1- 
4): 144-150.

Yue S, Pilon P, Phinney B, et al. 2002. The influence of autocorrelation on the ability to detect trend in hydrological series. Hydrological Processes, 16(9): 1807-1829.

Yue S, Wang C Y. 2002. Applicability of prewhitening to eliminate the influence of serial correlation on the Mann-Kendall test. Water Resources Research, 38(6): 4-1-4-7, doi: 10.1029/2001WR000861.

Zhang Q, Liu C, Xu C Y, et al. 2006. Observed trends of annual maximum water level and streamflow during past 130 years in the Yangtze River basin, China. Journal of Hydrology, 324(1-4): 255-265.

Zhao J, Huang Q, Chang J, et al. 2015. Analysis of temporal and spatial trends of hydro-climatic variables in the Wei River Basin. Environmental Research, 139: 55-64.

Zhou J, Liang Z, Liu Y, et al. 2015. Six-decade temporal change and seasonal decomposition of climate variables in Lake Dianchi watershed (China): stable trend or abrupt shift? Theoretical and Applied Climatology, 119: 181-191.

Zohrabi N, Bavani A M, Goodarzi E, et al. 2014. Attribution of temperature and precipitation changes to greenhouse gases in northwest Iran. Quaternary International, 345: 130-137. 


\section{Appendix}

Table S1 Characteristics of the selected synoptic stations over Iran

\begin{tabular}{|c|c|c|c|c|}
\hline Station & Longitude & Latitude & Altitude (m) & Climatic class \\
\hline Arak & $49^{\circ} 46^{\prime} \mathrm{E}$ & $34^{\circ} 06^{\prime} \mathrm{N}$ & 1708.0 & Semi-arid \\
\hline Ardebil & $48^{\circ} 17^{\prime} \mathrm{E}$ & $38^{\circ} 15^{\prime} \mathrm{N}$ & 1332.0 & Mediterranean \\
\hline Oroomiyyeh & $45^{\circ} 03^{\prime} \mathrm{E}$ & $37^{\circ} 40^{\prime} \mathrm{N}$ & 1328.0 & Semi-arid \\
\hline Esfahan & $51^{\circ} 40^{\prime} \mathrm{E}$ & $32^{\circ} 37^{\prime} \mathrm{N}$ & 1550.4 & Extremely arid \\
\hline Aqajari & $49^{\circ} 40^{\prime} \mathrm{E}$ & $30^{\circ} 46^{\prime} \mathrm{E}$ & 27.0 & Arid \\
\hline Omidiyyeh & $49^{\circ} 39^{\prime} \mathrm{E}$ & $30^{\circ} 46^{\prime} \mathrm{N}$ & 34.9 & Arid \\
\hline Ahwaz & $48^{\circ} 40^{\prime} \mathrm{E}$ & $31^{\circ} 20^{\prime} \mathrm{N}$ & 22.5 & Arid \\
\hline Iranshahr & $60^{\circ} 42^{\prime} \mathrm{E}$ & $27^{\circ} 12^{\prime} \mathrm{N}$ & 591.1 & Extremely arid \\
\hline Ilam & $46^{\circ} 26^{\prime} \mathrm{E}$ & $33^{\circ} 38^{\prime} \mathrm{N}$ & 1337.0 & Mediterranean \\
\hline Abadan & $48^{\circ} 15^{\prime} \mathrm{E}$ & $30^{\circ} 22^{\prime} \mathrm{N}$ & 6.6 & Semi-arid \\
\hline Abadeh & $52^{\circ} 40^{\prime} \mathrm{E}$ & $31^{\circ} 11^{\prime} \mathrm{N}$ & 2030.0 & Arid \\
\hline Abali & $51^{\circ} 53^{\prime} \mathrm{E}$ & $35^{\circ} 45^{\prime} \mathrm{N}$ & 2465.2 & Semi-arid \\
\hline Babolsar & $52^{\circ} 39^{\prime} \mathrm{E}$ & $36^{\circ} 43^{\prime} \mathrm{N}$ & -21.0 & Humid \\
\hline Bojnourd & $57^{\circ} 16^{\prime} \mathrm{E}$ & $37^{\circ} 28^{\prime} \mathrm{N}$ & 1112.0 & Semi-arid \\
\hline Bam & $58^{\circ} 21^{\prime} \mathrm{E}$ & $29^{\circ} 06^{\prime} \mathrm{N}$ & 1066.9 & Extremely arid \\
\hline Bandar Anzali & $49^{\circ} 27^{\prime} \mathrm{E}$ & $37^{\circ} 29^{\prime} \mathrm{N}$ & -23.6 & Very humid \\
\hline Bandar Abbas & $56^{\circ} 22^{\prime} \mathrm{E}$ & $27^{\circ} 13^{\prime} \mathrm{N}$ & 9.8 & Extremely arid \\
\hline Bandar Lengeh & $54^{\circ} 50^{\prime} \mathrm{E}$ & $26^{\circ} 32^{\prime} \mathrm{N}$ & 22.7 & Extremely arid \\
\hline Boushehr (Coastal) & $50^{\circ} 49^{\prime} \mathrm{E}$ & $28^{\circ} 54^{\prime} \mathrm{N}$ & 8.4 & Arid \\
\hline Birjand & $59^{\circ} 12^{\prime} \mathrm{E}$ & $32^{\circ} 52^{\prime} \mathrm{N}$ & 1491.0 & Arid \\
\hline Moqan & $47^{\circ} 55^{\prime} \mathrm{E}$ & $39^{\circ} 39^{\prime} \mathrm{N}$ & 31.9 & Semi-arid \\
\hline Tabriz & $46^{\circ} 17^{\prime} \mathrm{E}$ & $38^{\circ} 05^{\prime} \mathrm{N}$ & 1361.0 & Semi-arid \\
\hline Torbat Heidariyyeh & $59^{\circ} 13^{\prime} \mathrm{E}$ & $35^{\circ} 16^{\prime} \mathrm{N}$ & 1450.8 & Semi-arid \\
\hline Tehran & $51^{\circ} 19^{\prime} \mathrm{E}$ & $35^{\circ} 41^{\prime} \mathrm{N}$ & 1190.8 & Arid \\
\hline Jask & $57^{\circ} 46^{\prime} \mathrm{E}$ & $25^{\circ} 38^{\prime} \mathrm{N}$ & 5.2 & Extremely arid \\
\hline Boumousa Island & $54^{\circ} 50^{\prime} \mathrm{E}$ & $25^{\circ} 50^{\prime} \mathrm{N}$ & 6.6 & Extremely arid \\
\hline siri Island & $54^{\circ} 29^{\prime} \mathrm{E}$ & $25^{\circ} 53^{\prime} \mathrm{N}$ & 4.4 & Extremely arid \\
\hline kish Island & $53^{\circ} 59^{\prime} \mathrm{E}$ & $26^{\circ} 30^{\prime} \mathrm{N}$ & 30.0 & Extremely arid \\
\hline Jolfa & $45^{\circ} 40^{\prime} \mathrm{E}$ & $38^{\circ} 45^{\prime} \mathrm{N}$ & 736.2 & Mediterranean \\
\hline Chabahar & $60^{\circ} 37^{\prime} \mathrm{E}$ & $25^{\circ} 17^{\prime} \mathrm{N}$ & 8.0 & Extremely arid \\
\hline Khorramabad & $48^{\circ} 17^{\prime} \mathrm{E}$ & $33^{\circ} 26^{\prime} \mathrm{N}$ & 1147.8 & Semi-arid \\
\hline Khoy & $44^{\circ} 58^{\prime} \mathrm{E}$ & $38^{\circ} 33^{\prime} \mathrm{N}$ & 1103.0 & Semi-arid \\
\hline Dezfoul & $48^{\circ} 23^{\prime} \mathrm{E}$ & $32^{\circ} 24^{\prime} \mathrm{N}$ & 143.0 & Arid \\
\hline Doushan Tappeh & $51^{\circ} 20^{\prime} \mathrm{E}$ & $33^{\circ} 42^{\prime} \mathrm{N}$ & 1209.2 & Semi-arid \\
\hline Dogonbadan & $50^{\circ} 49^{\prime} \mathrm{E}$ & $30^{\circ} 20^{\prime} \mathrm{N}$ & 726.0 & Semi-arid \\
\hline Ramsar & $50^{\circ} 40^{\prime} \mathrm{E}$ & $36^{\circ} 54^{\prime} \mathrm{N}$ & -20.0 & Very humid \\
\hline Rasht & $49-37^{\prime} \mathrm{E}$ & $37-19^{\prime} \mathrm{N}$ & -8.6 & Very humid \\
\hline Zabol & $61^{\circ} 29^{\prime} \mathrm{E}$ & $31^{\circ} 02^{\prime} \mathrm{N}$ & 489.2 & Extremely arid \\
\hline Zahedan & $60^{\circ} 53^{\prime} \mathrm{E}$ & $29^{\circ} 28^{\prime} \mathrm{N}$ & 1370.0 & Extremely arid \\
\hline Zanjan & $48^{\circ} 29^{\prime} \mathrm{E}$ & $36^{\circ} 41^{\prime} \mathrm{N}$ & 1663.0 & Semi-arid \\
\hline Sabzevar & $57^{\circ} 39^{\prime} \mathrm{E}$ & $36^{\circ} 12^{\prime} \mathrm{N}$ & 972.0 & Arid \\
\hline Sarakhs & $61^{\circ} 10^{\prime} \mathrm{E}$ & $36^{\circ} 32^{\prime} \mathrm{N}$ & 235.0 & Arid \\
\hline Saqqez & $46^{\circ} 16^{\prime} \mathrm{E}$ & $36^{\circ} 15^{\prime} \mathrm{N}$ & 1522.8 & Mediterranean \\
\hline Semnan & $53^{\circ} 25^{\prime} \mathrm{E}$ & $35^{\circ} 35^{\prime} \mathrm{N}$ & 1127.0 & Arid \\
\hline Sanandaj & $47^{\circ} 00^{\prime} \mathrm{E}$ & $35^{\circ} 20^{\prime} \mathrm{N}$ & 1373.4 & Mediterranean \\
\hline
\end{tabular}


Continued

\begin{tabular}{|c|c|c|c|c|}
\hline Station & Longitude & Latitude & Altitude (m) & Climatic class \\
\hline Sahand & $46^{\circ} 07^{\prime} \mathrm{E}$ & $37^{\circ} 56^{\prime} \mathrm{N}$ & 1641.0 & Semi-arid \\
\hline Sirjan & $55^{\circ} 41^{\prime} \mathrm{E}$ & $29^{\circ} 28^{\prime} \mathrm{N}$ & 1739.4 & Extremely arid \\
\hline Shahroud & $54^{\circ} 57^{\prime} \mathrm{E}$ & $36^{\circ} 25^{\prime} \mathrm{N}$ & 1349.1 & Arid \\
\hline Esfahan (East) & $51^{\circ} 52^{\prime} \mathrm{E}$ & $32^{\circ} 40^{\prime} \mathrm{N}$ & 1543.0 & Extremely arid \\
\hline Shahrekord & $50^{\circ} 21^{\prime} \mathrm{E}$ & $32^{\circ} 17^{\prime} \mathrm{N}$ & 2048.9 & Very humid \\
\hline shiraz & $52^{\circ} 36^{\prime} \mathrm{E}$ & $29^{\circ} 32^{\prime} \mathrm{N}$ & 1484.0 & Semi-arid \\
\hline Tabas & $56^{\circ} 55^{\prime} \mathrm{E}$ & $33^{\circ} 36^{\prime} \mathrm{N}$ & 711.0 & Extremely arid \\
\hline Ferdows & $58^{\circ} 10^{\prime} \mathrm{E}$ & $34^{\circ} 01^{\prime} \mathrm{N}$ & 1293.0 & Arid \\
\hline Fasa & $53^{\circ} 41^{\prime} \mathrm{E}$ & $28^{\circ} 58^{\prime} \mathrm{N}$ & 1288.3 & Semi-arid \\
\hline Qazvin & $50^{\circ} 03^{\prime} \mathrm{E}$ & $36^{\circ} 15^{\prime} \mathrm{N}$ & 1279.2 & Semi-arid \\
\hline Qom & $50^{\circ} 51^{\prime} \mathrm{E}$ & $34^{\circ} 42^{\prime} \mathrm{N}$ & 877.4 & Arid \\
\hline Qouchan & $58^{\circ} 30^{\prime} \mathrm{E}$ & $37^{\circ} 04^{\prime} \mathrm{N}$ & 1287.0 & Semi-arid \\
\hline Kashan & $51^{\circ} 27^{\prime} \mathrm{E}$ & $33^{\circ} 59^{\prime} \mathrm{N}$ & 982.3 & Extremely arid \\
\hline Kerman & $56^{\circ} 58^{\prime} \mathrm{E}$ & $30^{\circ} 15^{\prime} \mathrm{N}$ & 1753.8 & Arid \\
\hline Karaj & $50^{\circ} 54^{\prime} \mathrm{E}$ & $35^{\circ} 55^{\prime} \mathrm{N}$ & 1312.5 & Semi-arid \\
\hline Kermanshah & $47^{\circ} 09^{\prime} \mathrm{E}$ & $34^{\circ} 21^{\prime} \mathrm{N}$ & 1318.6 & Semi-arid \\
\hline Konarak & $60^{\circ} 22^{\prime} \mathrm{E}$ & $25^{\circ} 26^{\prime} \mathrm{N}$ & 12.0 & Extremely arid \\
\hline Gorgan & $54^{\circ} 24^{\prime} \mathrm{E}$ & $36^{\circ} 54^{\prime} \mathrm{N}$ & 0.0 & Mediterranean \\
\hline Maku & $44^{\circ} 26^{\prime} \mathrm{E}$ & $39^{\circ} 20^{\prime} \mathrm{N}$ & 1411.3 & Semi-arid \\
\hline Maraqeh & $46^{\circ} 16^{\prime} \mathrm{E}$ & $37^{\circ} 24^{\prime} \mathrm{N}$ & 1477.7 & Semi-arid \\
\hline Masjed Soleiman & $49^{\circ} 17^{\prime} \mathrm{E}$ & $31^{\circ} 56^{\prime} \mathrm{N}$ & 320.5 & Semi-arid \\
\hline Mashhad & $59^{\circ} 38^{\prime} \mathrm{E}$ & $36^{\circ} 16^{\prime} \mathrm{N}$ & 999.2 & Semi-arid \\
\hline Mahabad & $45^{\circ} 43^{\prime} \mathrm{E}$ & $36^{\circ} 45^{\prime} \mathrm{N}$ & 1351.8 & Semi-arid \\
\hline Minab & $57^{\circ} 05^{\prime} \mathrm{E}$ & $27^{\circ} 06^{\prime} \mathrm{N}$ & 29.6 & Arid \\
\hline Nowshahr & $51^{\circ} 30^{\prime} \mathrm{E}$ & $36^{\circ} 39^{\prime} \mathrm{N}$ & -20.9 & Very humid \\
\hline Hamedan & $48^{\circ} 32^{\prime} \mathrm{E}$ & $34^{\circ} 52^{\prime} \mathrm{N}$ & 1741.5 & Semi-arid \\
\hline Hamedan (Nowjeh) & $48^{\circ} 43^{\prime} \mathrm{E}$ & $35^{\circ} 12^{\prime} \mathrm{N}$ & 1679.7 & Semi-arid \\
\hline Yazd & $54^{\circ} 17^{\prime} \mathrm{E}$ & $31^{\circ} 54^{\prime} \mathrm{N}$ & 1237.2 & Extremely arid \\
\hline
\end{tabular}

